\title{
John Hick's Global Theology of Death and Immortality in Conversation with the Yoruba-African Philosophy of Afterlife
}

\author{
Titus S. Olorunnisola Ph.D. (Corresponding author) \\ ACOM/Sydney College of Divinity, Melbourne Australia \\ University of Divinity, Melbourne Australia \\ 29 College Crescent, Parkville VIC 3052 \\ E-mail: titusolorunnisola@gmail.com
}

This research was financed by the Faculty of Theology, VU University Amsterdam.

\begin{abstract}
This article examined John Hick's speculative philosophy on the subject of death and immortality and compares it with the religious philosophy of the Yoruba-African people. Hick's book, Death and Eternal Life forms the primary resource for this exploration by considering various fields which gave impetus to Hick's development of a global theology of death. An ethnological approach revealed a distinct philosophical thought about Yoruba people's philosophies about death and life after death. A comparison of these constructions from different traditions revealed that there are similarities as well as divergences. Indeed, a global theology of death is possible only when all available data are explored and every view has been heard.
\end{abstract}

Keywords: African Philosophy, John Hick, Death and Immortality, Life after Death, Yoruba Philosophy, Near Death Experiences, Reincarnation, Pareschatology

DOI: $10.7176 / \mathrm{JPCR} / 44-04$

Publication date:June $30^{\text {th }} 2019$

\section{Introduction}

There is a lively debate on the subject of life after death. There seem to be at least three schools of thought in this regard. First, there are those who consider the possibility of another life simply because of their religious inclination. Such people would accept it because of their piety and religious dogma. Second are those who would respond by simply denying it, as it defies human rationality and empirical verification. This group would argue that it is of no need, it is not possible. C. D. Broad observed in his autobiography, "so far as I can tell, I have no desire to survive the death of my present body, and I should be considerably relieved if I could feel much surer than I do that no kind of survival possible" (Cheetham 2003:72). The third group may simply stand on the fence expecting to see whatever happens at the eschaton. John Hick does not affirm the possibility of life after death because of his religious convictions alone but also for his philosophical justification and verifications taking advantage of other religions and non-western philosophical traditions to develop his hypothesis on this phenomenon.

Hick points out certain observations on the nature of the discussion on the subject of death and immortality. To him, the best way to begin such a discussion is to start from the angle of a religious tradition with its social corresponding worldview (Hick 1976:27). The participant may not necessarily affirm that worldview but essentially has it as a locus standi.

\section{Methodology}

I used anthropological and analytical methods to examine the Yoruba-African philosophies of the afterlife and John Hick's idea of global theology of death respectively. Hick's Death and Eternal Life (1976) provides insights into his notion of death and immortality. I used a qualitative method on the part of the Yoruba philosophy of death and immortality as supplementary to the available literature. The author administered some questionnaires and conducted interviews in the summer of 2008 at Ogbomoso, and Ijannikin, Lagos State, Nigeria. The aim of the questionnaires and interviews are to obtain information for this research.

I will begin by investigating Hick's development of global theology of death by focusing on human components and turn to Yoruba philosophical formulation on the afterlife. I will come back to compare the idea of death and afterlife on both sides.

\section{Process of Hick's global theology of death}

In the book Death and Eternal Life, Hick sets out two main goals for his writing. The first is that of an apologist. $\mathrm{He}$ argues that every religion in its understanding of human existence, as a matter of necessity, embraces a notion 
of immortality, without which it is inconceivable (Hick 1976). While philosophy speculates about human existence, religion goes beyond by using those speculations to form a system of religious beliefs. Hick states further, "I shall argue that it (belief in immortality) is not ruled out by any established scientific findings or by any agreed philosophical arguments" (Hick 1976:11). He links diverse eschatological thoughts to various religious interpretive analyses. Hence, he proposes to the fill gap created by the religious analyses of diverse religious worldviews by harmonizing these traditions.

The second goal is an attempt to create a global theology of death. A global here is one that goes beyond one-tradition effort, but "an inter-cultural as well as interdisciplinary approach" (Hick 15). He distinguishes between two aspects of religion:

Its central affirmations about human destiny- these affirmations being, ultimately, true or false and on the other hand, the mythology, with its often rich poetic elaborations and its concrete cultic expressions, which has grown up along the central affirmations in the same cultural soil but which is not in the same sense true or false (Hick 1976:29).

These two aspects of religion are intertwined. The central affirmations of the nature of reality specify the teachings and convictions; the mythological aspect points to ways and means of convincing the adherents of such realities. The nature of such realities can either be true or false. Hence, since the affirmations about the nature of reality can be absolutely true or false or partly or otherwise, the theologies of various religions can be compared with the synthesis of the similarities and differences to form a global theology of death. A global theology is not synonymous to a united theological thought but one that entails a wide range of observations arising from the comparison of concepts from various cultures, religious traditions, and openness to all data. Hick observed that the only way to formulate a global theology is to look into the comparison of various theological affirmations of world faiths.

As a contrast to his proposal, Hick rejects that he is constructing a global religion - which attempts a unification of worldviews. In order to achieve this task, Hick disagrees with any form of 'Ptolemaic' view. A 'Ptolemaic view', according to Hick, is "the conviction that one's own religion is at the centre of the religious universe and provides a touchstone for the truth of all other faith-worlds" (Hick 1976:30). This view lays a claim to be in possession of the absolute truth that one feels indifferent to the ideas of other faiths. To avoid a 'Ptolemaic' view in the modern age, one has to be objective in considering religious truths - by placing one's religious standpoint on the same level with other religions.

Hick sees the need to consider almost all religions, philosophies, and even parapsychology. Hick's religious and philosophical presuppositions are within Christianity and Western tradition respectively. Nevertheless, he believes that all these are "responses to various overlapping aspects of the same Ultimate Reality" (Hick 1976: 31).

\subsection{An understanding of the human composition}

A human being has physical, psychological, and metaphysical compositions. The physical aspect of the human person is called the body or flesh. Words that have been used interchangeably to describe the non-physical aspect of the human person include mind, soul, self, I, person, spirit, ego, consciousness, psyche, superego and mentality to mention a few. Let us consider different components of the human person to see how they contribute to Hick's formulation.

\section{Mind/Brain}

The father of modern philosophy, Descartes attempted a thoughtful presentation on the mind and states that it is "a thinking thing" that 'affirms', or 'doubts' or "a thinking being" (Haldane and Ross 1976:150). For Descartes, the mind is identifiable with the features of mental consciousness. There are various options available on the concept of the mind and body in an attempt to understand the survival of a conscious self. The monistic option states that the mind/brain refers to the same entity and can be used interchangeably. The second option is dualism. It considers the body and mind as "distinct entities" of different kinds, but with diverse interpretations of their relationship. The first interpretation is the epiphenomenalism thesis which states that the mind is solely dependent upon the body and cannot function effectively without it (Hick, 112). Another dualist interpretation is that although the mind and body are different entities, they have a mutual level of joint influence on each other. Nonetheless, the mind cannot function without the body, and the mutual interrelationship of the two are required for the human conscious self. The third adds that besides the explanations in the second interpretation, the mind has the potential for the survival of the death of the physical body. Concerning this, Hick categorically states:

I do not claim that a capacity of the mind to survive the decay of the body can be established by philosophical argument, but I claim that it cannot be excluded either by philosophical argument or by 
empirical evidence. Inspection of the notions of mind and body and evidence of mind/brain correlation, I shall argue, leave the door open, or at least unlocked, to a belief in the survival of the conscious self (Hick 112).

As shown above, Hick critically evaluates the available options on the mind/brain identity, epiphenomenalism, and opts for dualism. Hick further stresses that the mind/brain identity theory (either in a monistic or dualistic view), in this thesis though have different conceptual meanings nevertheless, refer to the same thing, the brain.

Hence, the mind/brain identity theory strongly affirms that the events in both places are contingently related. It is, therefore, an empirical hypothesis; confirmable or disputable through the empirical evidence, "that thoughts are identically the same as brain processes" (Hick 1976:113). However, Hick argues that there are a number of shreds of evidence for the mind/brain correlation, for instance, brain-mapping and progressive identification of the specific brain activity related to a particular mental activity are rather to substantiate mind and brain correlation other than proving mind and brain identity. Hick observes that the examples above 'morning star and evening star' are just physical elements which have different elements but with the same cognitive understanding in different situations can be identified differently. He harnesses it further that such analogies are not sufficient to convince one of whether the physical and mental events are identical. Hick seems to conclude that the idea of mind/brain identity theory cannot be sufficient to dispose of the issue of the mind's survival in eternal life.

\section{The Soul}

Most of the attributes discussed on the mind are often used for the soul as well, or at least, the two words (mind and soul) are sometimes used interchangeably. It is interesting also to note that it is very rare for scholars in the field of religion to use the word 'mind' pertaining to discussion on immortality. While philosophy accepts the usage of the two words (mind and soul) but often in different contexts, it seems that since the speculations on immortality have a more religious undertone, religion might prefer the usage of the soul while philosophy feels more at home with the mind. Most of the reference here will be to the soul.

The soul is simply identified as a non-material component of the human person. The Greeks conceive it as the life-giver to the body, 'consisting' of thoughts and personality (Routledge Encylopedia of Philosophy s. v. 'Nature and Immortality of the soul'). It originates from the Greek word psyche ('life, spirit or consciousness'). The main point that helps to understand the concept of immortality is the nature of the soul. Socrates described the soul as the very essence of a person, the very being of man that makes a human who he is. It is an incorporeal and eternal 'being' that dwells in the human body. Plato, in developing the thought of his teacher, Socrates, added that the soul is responsible for mental acts, feelings, emotions, and desires (Routledge Encylopedia of Philosophy). Plato asserts that the soul is simple, it has no part. The body and soul can interact and can have a complementary influence on each other. He further states that at death, the soul separates from the body into another life. Aristotle in a contrasting view thought of the soul as having a 'form' namely a way of behaving and thinking- "a human having a soul just is the (sic) human behaving (by moving parts of the body) and thinking in certain characteristic human ways" (Routledge Encylopedia of Philosophy). Hence, for Aristotle, the soul does not exist without the body. In the thirteenth century, St. Thomas Aquinas developed the Aristotelian concept within Christian doctrine. Soul for Aquinas is a form, which could temporarily exist without the body where it lives naturally. He taught that since the soul is formless and free of matter it cannot be destroyed by any natural force.

The belief in life after death as expressed in Christian theology took over Plato's views as further developed by St Thomas Aquinas. If the soul is conceived as a distinct entity from the body and could exist temporarily apart from the body where it is housed, then the thought of an after-life existence is conceivable. This discussion is not complete without saying something about the body.

\section{The Body}

The final component of the human person is the material self that houses the soul. There are no such arguments, if any, from religious and philosophical perspectives on the nature of the body. It is generally believed that it has finite existence (as against the soul). Despite the existing dichotomy between the soul and body, there is a great measure of interconnectedness between them. Just as the body does not exist without the soul as its powerhouse, so also the soul is not effective in active earthly existence without the body.

\subsection{Parapsychology}

The argument of determinism is logically not persuasive enough within the view of dualism. Hick finds a better substitute in the findings of the parapsychology (Hick 1976:129-146; Cheetham 2003:72-74). These include the phenomena like telepathy, Near Death Experiences (NDEs), and Extrasensory perception (ESP) such as 
clairvoyance, spiritual mediumship or trans-mediumship among others. These set of experiences account for Hick's pieces of evidence of survival of bodily death.

H. H. Price described telepathy as "the communication of impressions of any kind from one mind to another independent of the recognized channel of sense" (Price 1995:35-39). It involves the transferring and deciphering of information from a distant person. There are two sides to the involvement in the process; the side of 'the agent'- the person from whom the message is being transferred and 'the percipient'-the receiver of the communication. The agent who is in a way related to the percipient is passing through a severe, drastic crisis experience, in the form of illness, accident, death, etc, and the percipient is caught in a feeling of distress or anxiety. This feeling is expressing the situation of the relative but not in clear terms. The latter has a dream, a visual or auditory hallucination or a form of emotional restlessness and bodily impression on the side of the percipient that makes the agent close in an unusual way around the percipient, yet the agent is not present physically (Vassy 2004:323-350). If one agrees by scientific evidence that this phenomenon is mind induced, then it suggests a possibility of the survival of bodily death.

Another parapsychological dimension is the cases of the NDEs - an occurrence in which the subject, through circumstances of an accident, illness or cardiac arrest or loss consciousness, the electrical activities in the brain partially stop, faced with the imminence of death with certain unusual experiences but later came back to life. Christopher Cherry uses a striking title for his article when he asks, "Are Near-Death Experiences really suggestive of Life after Death?" (Cherry 1995:145-163). In Cherry's analysis, this phenomenon involves five sequential stages: "peace, body separation, (out -of -body experiences and autoscopy); entering the darkness (or the tunnel); seeing the light, and entering light" (Cherry 146). During the process, the experient encounters the 'being of light', and may converse with deceased relatives or friends. As the experient comes out of the body, the conscious self is able to master the happening in the other world independent of the physical brain. The experiences during this state may presumably give a glimpse of heaven and hell as depicted in the dualism of the eschatological formulations of many religions (Lorimer 1995:164-172).

Those who narrate NDEs have done so because of certain experiences which they were privileged to survive. Although, their brains ceased in the process but the mind retained certain consciousness which was later reconfigured by the brain when they regained their consciousness. It shows that the mind influences the brain and vice versa - a dualistic perspective within the sphere of parapsychology. We will briefly look into the dimension of medium communications.

Psychical research has also turned to the side of trans-medium communications with the dead in the quest to verify the survival of bodily death. The process of medium communication is a bit different from telepathy. The process involves the spirit of the dead, the communicator who is often referred to as the medium and the living persons who attend the 'mediumistic séance' known as sisters (Hick 1976:129). The spirit relays certain purported hidden messages through the speech organ of the medium who is an intermediary between the spirit and the sisters. Sometimes the mannerism of the dead person is personated in the process as if the deceased is still alive. That the spirit of the dead can be summoned in a conversation presupposes that the deceased exists somewhere and somehow in another world. If this is reasonable at least by our present faintly knowledge of the eternal now and the eternal life, that we are able to accept the above evidence as tenable, it is possible to say that we now have another tentative evidence for the survival of bodily death.

However, there remain some questionable aspects of this paranormal phenomenon. For example, the spirits are often found saying little about their own existence that almost nothing is known about them except the content of major discussion for which they are invoked. They are often fraudulent hence, the veracity of the "unconscious fraud hypothesis" (Hick 1976:131). A research was conducted in 2005 to ascertain the correlations between paranormal beliefs and religiosity in Austria (Hergovich, et al, 2005: 293-303). The participants were drawn from Protestant denominations, the Catholic Church and those without any religious affiliation. Elements of religious and paranormal beliefs such as psi, witchcraft, superstition, spiritualism, extra life, precognition, and belief were tested. The researchers concluded that "both religiosity and paranormal belief are multidimensional constructs that do not allow a simple answer to the question of whether paranormal belief and religious belief are related" (Hergovich, et al 2005: 302). J.E. Kennedy (2005:263-292) rather attributes the belief in the paranormal phenomena and its practices to personality traits.

Nonetheless, parapsychology with its findings advocates certain possibilities that are considered evidence on the survival of bodily death. Though the argument is inconclusive in that it defies empirical verification, it is probably intelligible that the thought of an afterlife cannot be overruled. Hick himself is clearly and certainly convinced that the phenomena of the paranormal are not logically sufficient to prove the survival theory. He asked, "where does the empirical research leave us? It leaves us at the present in uncertainty" (Hick 1993:187). However, Hick asserts, "We must not mistake absence of knowledge for knowledge of absence!" (Hick 1993:187). There is a need for further investigation at the present to avoid the present state of uncertainty. 


\section{Between Death and the Ultimate State}

The belief in the historic concept of after-life and the proposition on the survival of bodily death which leads to a conceived immortality (Geach 1973:11-21) has been established through various evidences in the previous sections. If this is so, then there exists a gap between the period subsequent to death and the ultimate state. If the thought of Hick is followed carefully, his propositions can be interpreted in two ways. He gives an interpretative analysis of the existence of the human person, namely the soul/mind and body in the present life and suggests a possible place for a much-desired afterlife. Let's take a clear look at The Disembodied Life, the 'Replica' Theory of Resurrection and Reincarnation.

\subsection{The Disembodied Life}

Having established the possibility of an afterlife, Hick moves on to examine what it would mean to live as an ethereal being - living consciously without a physical body. His proposition shall be considered in the light of the formulations of the philosopher H.H. Price. Price had earlier put forward the proposition in his article titled "Survival and the Idea of "Another World" (Price 1973: 21-47). He described the next world as one of a sort of a dream-like-world that is full of mental images as replacement of current human senses and all that exists now. The dead would have hardly realized they were dead. He further claimed:

Left to our resources, as we should be in the Other World, with nothing but our memories to depend on, we should probably be able to form only generic images of such objects. In this respect, an image-world would not be an exact replica of this one, not even of those parts of this one which we have actually perceived (Price 1973:26).

Price's article relates to the presumed relationship within the existence of the discarnate minds in another world. There in another life, as he proposed, would be the kind of experiences that correspond to the level of that existence. The imaging would replace sense-perception since sense-perception of the present world would be no more. The disembodied minds, through the aid of extra-sensory perception such as telepathy, can communicate more frequently. For Price, being 'living' or 'alive' in this way should not be construed as having physicochemical processes and experiences but rather a psychological sense of "having experiences of certain sorts" (Price 1973:27). In the next world, the mental images would create auditory images, smell images and animals. Some of these images may relate to one another but in any case, all would be a representative and substitute for the material objects.

Again, the next world would be a world of memories and desires. Price writes,

Their memories and desires (of the discarnate minds) would determine what sort of images they had. If I may put it so, the 'stuff' or 'material' of such a world would come in the end from one's memories and the 'form' of it from one's desires. To use another analogy, a memory would provide the pigments and desire would paint the picture (Price 1973:38).

The desires and memories are invariably the extensions of those experienced in the present life. Both the expressed and repressed desires would find a place to exist with the disembodied self in creating suitable images since they were conceived during the present life. Considering this view, Hick finds the Achilles' heel in Price's formulation:

There is however in his theory a tension between the idea of the formation of a post-mortem world by the power of desire and the idea that such a world is common to many minds in virtue of telepathic links between them (Hick 1976:276).

His contention is on two principles of Price; mind-dependent nature in the post mortem world and the formation through the power of human desire. In this case, there can never be unity within human desires if the concerned individuals are not in agreement. He sees the wish-fulfillment principle to be more suggestive of a 'private' or 'individualistic' world other than a public world with telepathic links for communication and interaction. Since no such individualistic world exists even in the present life where individual's desires are exclusively private but rather has connecting points through which interaction and communication take place, the wish-fulfilling principle is not conceivable (Hick 1976:270).

Hick further raises a theological criticism of a post-mortem world fashioned by human desires corporately or individually on the account of his Irenaean theodicy - as the soul-making process. He proposes that since 'a person making process is taking place in this life, that process is seldom (if indeed ever) completed by the time of bodily death' (Hick 1976:273). According to Hick, humans are animals at birth but are children of 
God in destiny. ${ }^{1}$ Justifying this thesis, Hick conjectures that a world that is full of challenges and possibly suffering would be a more probable place for the making into the human destiny rather than a world where human desires are easily met (Hick 273). For this reason, a wish-fulfilling world would only play the balancing role of "character formation would be to refine and purify the structure of desires and dispositions that have already been developed on earth" (Hick 274). It is however clear from the foregoing that the goal of corporeal living in Hick's and Price's thought are at variance. For Price, it is "to provide us with a stock of memories out of which an image-world may be constructed when we are dead" (Price 1995:266). For Hick, it is to acquire enough purging of souls towards attaining human destiny (Hick 1976:273-276). Faulting Price's argument on the form of disembodied life, Hick developed the 'replica' theory as a plausible option.

\subsection{The 'Replica' Analogy of Resurrection as an argument for (Re-embodiment)}

Hick is famous among other things for his hypothesis on re-embodiment. It has at the same time attracted a lot of discussion and debate. His interest is mainly to re-present a conception of the resurrection of the person in such a manner that it is acceptable to a modern philosophical and scientific mind. He sees it as a more intellectually plausible alternative to what has been earlier proposed by H.H. Price and the patristic view on the resurrection. The patristic view of resurrection holds that after bodily death, the soul experiences a period of interim or sleep until the eschaton. At the resurrection, there is a re-embodiment which brings back a human being into a full physical form. The patristic view of resurrection is illustrated in the diagram below.

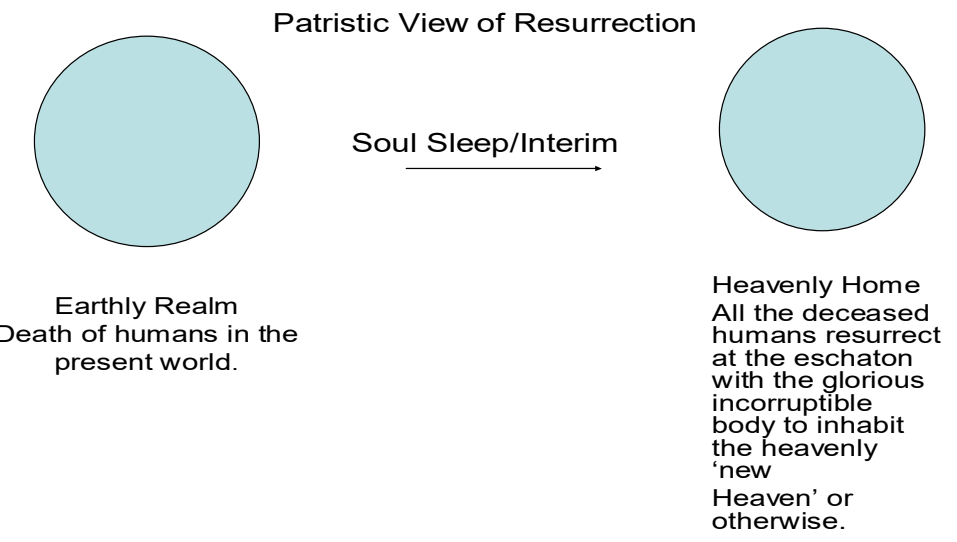

Fig 1. Patristic view of resurrection of the body (source: author)

To achieve his aim, Hick rejects the patristic thesis on the resurrection of the body (the church, as well as Christian theology, has always interpreted the resurrection of the person as the reassembling of the original body particles) and proposes that the resurrection will most probably be an event instantaneous to or shortly after a bodily death with a new and different body specially fashioned for its existence in another life. Hick's analogical 'replica theory' has it that the resurrected person will appear in the same personality with the former psychophysical and chemical 'replica' of the deceased (Hick 1976:280). This idea is presented in the diagram below:

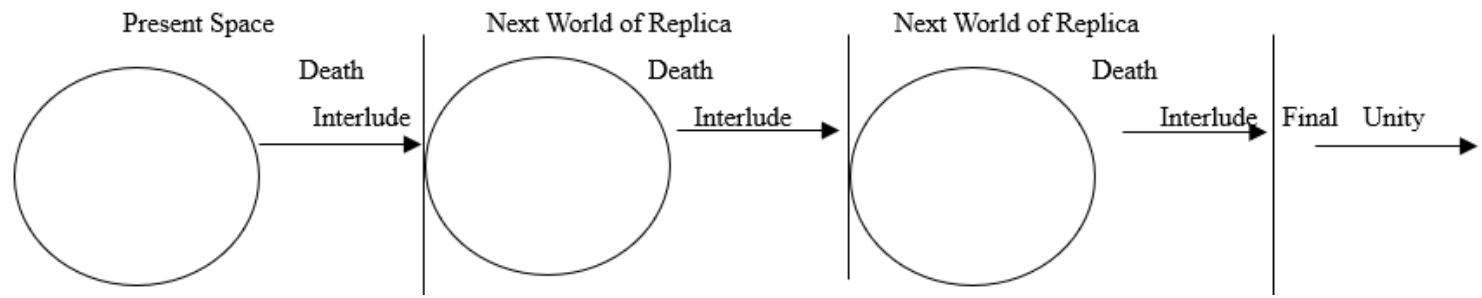

Fig 2. Hick’s "Replica” Analogy (source: author)

\footnotetext{
${ }^{1}$ For Hick's comprehensive thought on Irenaean theodicy, see John Hick, Evil and God of Love (London: Macmillan Co, 1968).
} 
Hick conceived an idea of two worlds or spaces that co-exist in an independent order with different contents and adaptability. He does this through a three-fold illustration to drive home his point. In the first place, he considers the disappearance of a person at a particular location in this world and instantly appearing at another place.

For example, at some learned gathering in London one of the company suddenly and inexplicably disappears and the next moment an exact 'replica' of him suddenly and inexplicably appears at some comparable meeting in New York. The person who appears in New York is exactly similar, as to both bodily and mental characteristics, to the person who disappears in London. There is continuity of memory, the complete similarity of bodily features, including the fingerprints, hair and eye coloration and stomach contents, and also of beliefs, habits, and mental propensities. In fact, there is everything that would lead us to identify the one who appeared with the one who disappeared, except continuous occupancy of space (Hick 1976:280).

Hick then moves on to liken the analogy to the case at stake, London and New York as representing two existing analogous spaces. As a replacement for transference, it would be a form of transportation into the world of the 'replicas'- where the 'inhabitants' would identify one another in a form of public other world (Hick 285). The second hypothetical case brings one closer to the idea of resurrection. The supposed disappearance would be understood as a sudden death. The person dies suddenly at London and the exact 'replica' of the deceased just as before death comes to exist in New York with the identity and memory until the point of death. With this identity, he argues, whoever sees the 'replica' would unquestionably identify him as the deceased (Hick 284).

The third case relates most to the idea of 'replication.' It is such that Mr. X dies in this world and his exact 'replica' did not appear anywhere on this earth but appears instantly or shortly thereafter as a resurrected 'replica' in another space. According to this view, the 'replica' would be an exact psycho-physical being just as he was before death, recollecting all the previous experiences. He is convinced that the:

Resurrected persons would be individually no more in doubt about their own identity than we are now, and would presumably be able to identify one another in the same kinds of ways and with a like degree of assurance as we do now (Hick 285).

However, the most problematic aspect of this thesis is the identity and uniqueness of the 'replica'. It is debatable if the 'replica' is indeed the same person as the deceased or if the 'replica' maintains the same identity before and after bodily death. Hick on his part retains his thought that he intentionally used the inverted commas "to mark the difference between the normal concept of a replica and the more specialized concept in use here" (Hick 253). The normal concept of a replica is when the original and the replica (a copy) can exist simultaneously but here he chooses to imply it by 'replica' since the original and a 'replica' exist in consecutive order.

Certain questions are not answered yet regarding the identity of the 'replica'. These questions shall be referred to later in chapter three. For now, it is possible to say that Hick's proposition finds total fulfillment in theistic trustworthiness. Stephen Davis's position supports this thought; (Cheetham quotes), "My continuing identity through time as the person that I am, then, is based in the first instance not on my own properties but on the fact that God sustains and upholds me as that being by recognizing and calling me" (Cheetham 83).

Both the Patristic concept of resurrection and the 'replica' theory are structured on the theistic belief. There is every tendency for the multiplicity of the replicas and this does not rule out the possibility that God will create only one after now. The thought of Hick as shared in this section from every indication avails the possibility for further research to be able to find a solid ground on this issue. This might be a radical alternative which Hick intended to suggest, yet he is not without being skeptical that our logical attempt to coherently pursue this search beyond here will certainly retain a measure of vagueness within our present limited knowledge. Another still exists.

\subsection{Reincarnation}

This is one of the oldest religious concepts that has been emphasized as another possibility on the issues of afterlife. It is popularly referred to as the eastern alternative. It is predominantly present in the Mahayana Buddhism and Hinduism and other religious traditions in the East. Reincarnation holds that life and existence are in a cyclic form. It is a corrective measure for all forms of inequalities in life; some are rich, others are poor, some are freeborn but others slaves, some are born in a class society while others in a class free, some are very fortunate in life while others are not, some live to old age while others die at infancy among others. It is affirmed that the conditions of the previous life determine this present life and the conditions of this present life will determine that of next life. The operative principle on which reincarnation stands is called karma- a spiritual cum natural principle undergirding the consequences of all human actions. The understanding of this law is seen in the words of R.K. Tripathi: 
The law of karma along with the doctrine of rebirth has the merit of solving one great problem of philosophy and religion, a problem which is a headache to western religions and which finds no satisfactory solution in them. India religions relieve God of this responsibility and make our karma responsible (Hick 108-109).

Reincarnation hypothesis is based on the transmigration of the soul, that is, the self-transferring from the body (at one death) to another body (at another birth). Hence, every human is subject to several rebirths in countless times but the conscious recollection of the memory of the previous lives is often terminated by the two events of death and rebirth. One may alternate race, sex, country of birth and so forth. It is challenging to conceive a linkage between one life and another.

If the life of a reincarnated person is connected with a series of previous lives and the rebirth does not occur immediately after the exit of the person, the question may be raised as to what happens to the soul awaiting another embodiment? Hywel Lewis attempts to answer this question by saying that the seeming difficulty will be solved "provided the soul is credited, in the intervening state, with some kind of experience or activity" (Lewis 1973:94) of which he did not give any insight. It seems probable hence, following the earlier principle of cause and effect or to simply put karma, on which the reincarnation is based, the soul in-between its embodiment would experience a 'purging' that would prepare it for the next cycle of existence. If this is tenable then, we can say that the experience of such 'purging' would refashion in a metamorphosis, some to a classless society, and others to a class system, some to animals or plant or even insect or a better and intelligent person.

\section{Pareschatology}

Here we turn to Hick's findings on what happens to the individual after bodily death since the conscious self or ego will continue to exist without immediate attainment of the highest state, which gives the possibility of an interim state. In this way, he did not appeal to logical reasoning as in other aspects of his previous examinations but purely attempts to synthesize the different aspects of the earlier findings. In order to establish what this state is like, he pointed to the Tibetan Book of the Dead and the Western medium communications.

\subsection{Tibetan Book of the Dead}

Tibetan Book of the Dead describes the Bardo (literally interpreted bar, 'between', do, 'two'), hence, the state between death and rebirth. As part of the experiences of the soul within the few days to its detachment from the physical body, it enters the first Bardo state, where it is surrounded by light, even the Ultimate Reality. If the soul so desire, it could enter the nirvana (the complete salvation), that seldom occurred in cases of individuals who have encountered a completed series of self-purification; in this case it will be joined with the Light and be clothed in karmic body of his past deeds and thoughts never to return to earth again. After this, the soul comes across the good and evil powers. When the soul approaches, the torment of the evil power draws near. An interception will be made first to attract the soul into the eternal Buddha-worlds of bliss by good powers. The soul contends to preserve its self-identity. The soul will further experience inescapable judgment and punishment in various corresponding hells. The soul will then move to the third bardo (Lidpa Bardo) where it will be reunited with another body and world consequent to its karma. Then the cycle of birth, death, and rebirth starts afresh. Hick concludes on the note that it is the soul that creates its post-mortem world for itself in conformity with its beliefs (Hick 1976:403).

\subsection{Summary of Hick's global theology of death}

Hick's global theology of death is conceivable using various evidences available from a wide range of human disciplines. It does not only appease to reasoning but it is also verifiable to a great extent within the confinement of present diverse religious claims, knowledge and philosophical presuppositions. My investigations in this section is an assessment of Hick's philosophy and theology has been on the nature of death to humans, what happens to an individual in death and what and where is life after death?

To these questions, I can conclude following Hick that human nature is preferably conceived as three parts, body, soul/mind, and spirit or Maya. At death, the soul separates from the body (surviving the bodily death) while the body decomposes. The soul then re-embodied to continue in another life. The much-desired after-life in Hick's thought would eventually be achieved after a successive order of 'replica' bodies in corresponding spaces. Death will terminate each after-life until the person is ready for the attainment of the Ultimate state. Replica theory, therefore, is neither a fact nor an already verified thesis but an intellectual proposition on the perspective of understanding of the immortal bodies. 


\section{The Yoruba ${ }^{1}$ Philosophy of afterlife}

Method

My discussion in this section will be primarily anthropological. The nature of African philosophy is quite different from the Western. Unlike what has been done in the previous sections, interviews conducted will be brought into the text. The search in this section will be primarily limited to Yoruba notions of death and afterlife. However, it is imperative to spell out certain assumptions that will guide the discussion on the notion of death and immortality among the Yoruba people of Nigeria. These presuppositions will guide our inquiry in this section (see fig.3).

1. The Yoruba-African worldview is essentially and primarily spiritual and hierarchical in nature with Olódùmarè (God) at the apex level. Hence, any philosophical speculation in this context needs to reflect this.

2. The Yoruba-African cosmological view does not maintain an exclusive separation between the world of the spirit and the physical, between the pre-mortem and post-mortem world.

3. For a well-informed philosophical notion to be considered in the context of the Yoruba people, all the available related philosophical languages and sources such as the oral traditions, proverbs, and Ifá literary Corpus must be properly explored so as to arrive at a meaningful and reasonable conclusion.

\section{Understanding of the Human Person}

John Mbiti a notable Kenyan philosopher of religion has described the African ontology as one that "is basically anthropocentric" in which mankind occupies the central position in relation to the universe, and "it is as if God exists for the sake of man” Mbiti 1969:92).

\subsection{Yoruba Creation Myths}

Perhaps one may have a better grasp of the Yoruba concept of human personality by first taking a brief look at the Yoruba creation myths. The Yoruba creation myths are very close to the Judeo-Christian creation accounts where God is pictured as forming humankind from the dust and giving him the breath of life. There are two wellknown myths in this regard. One of the myths, as narrated by Bolaji Idowu (1962:169-184; Ekanola 2006:41-51), has it that the arch-divinity, Òrìsà-Nlá formed humans from the dust. The Supreme Being Olódùmarè supplies the èmí (life/spirit) into the Ara (body) to quicken it. The èmí (life or spirit) is understood as the life-giving force of the body. The Yoruba sees the èémí (breath) as an extension of èmí (life). The person's Orí (personality self) kneels before Olódùmarè to "choose or receive or have the destiny affixed to it" (Idowu 1962:174). The three ways in which the person acquires his destiny are called À-kúnlè-yàn (that destiny which is acquired by kneeling), à-kúnlè-gbà (that destiny that is received by kneeling) and àyàn-mó (that which is affixed to one). After the selection of the ori, the person is then considered as a full human being. The person then proceeds on his journey into the world. He arrives at the gates of heaven; there he encounters the Oníbodè, (the Gate Keeper) who must ask certain questions. The person then recounts his chosen course on earth. The Oníbodè finally seals

\footnotetext{
${ }^{1}$ The Yoruba are people known for their wide philosophical sayings in Nigeria, Africa. The name Yoruba describes a number of semi-independent peoples highly linked by geography, language, history, culture, philosophy and religion. The Yoruba people, of whom there are more than twenty-five million, occupy the South-Western part of Nigeria along the Benin Republic border and extends into Benin Republic. The existence of the Yoruba people in this region of the country is often dated back to about $4^{\text {th }}$ century B.C. due to certain archaeological facts and earlier historical testimonies. Most live within the borders of the tropical forest belt, but the remnants of the powerful Oyo kingdom include groups that live at the fringes of the northern savannah grasslands. Archaeological evidence suggests that the ancestors of the Yoruba may have lived in this same general area of Africa since prehistoric times. The slave trade of the mid-18th century had a significant effect on the region of West Africa. Slaves of Yoruba descent were resettled in Cuba and Brazil, this avails the opportunity for the spread of Yoruba culture and philosophy in these areas. They are still there till today.

Historic religious and philosophical distinction among the people is held in high esteem. Some of these are preserved and transmitted as cultural heritages over the years from one generation to another. Distinct among these ideas is the thought and elements of death and immortality. It is core in philosophical, religious and cultural strands of the people. It is expressed in the form of proverbs, wisdom sayings in oral traditions that guide the connection between family and community life. People are careful in their attitude because of the belief in after-life. Its main source is the Ifá corpus which is highly honoured for its wisdom when consulted (in divination over issues of life). It encompasses diverse issues, instructions and warnings and is expressed in the form of oral stories, wisdom sayings, adages, and proverbs.
} 
the destiny. This is then followed by birth.

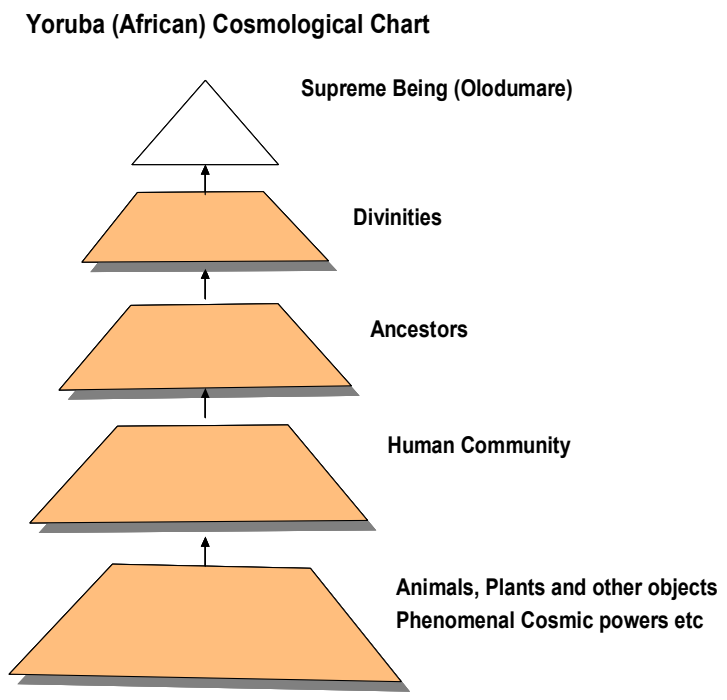

Fig 3. Yoruba Cosmological chart (source: author)

The second myth as given by Wande Abimbola (1976:113-132) who traces his source to the Ifá poetry is similar to this but with a little variance. Abimbola's account agrees with the process of the creation of the preexistent 'person' but amplifies the process of the selection of Orí (personality self) in heaven. After Olódùmarè has infused èmí (life/spirit), which is part of the divine breath into the body the person is now living but not totally completed. Shortly before coming into the world (the duration is not stated in any of the known sources) the 'person' goes to the house of Ájàlá Alámò, (a porter responsible for the making of heads in heaven) to select the head. Ajàlá Alámò does his things in his own way, sometimes he puts finishing touches to the pottery head, and sometimes he does not (Abimbola 1976:116). Invariably the 'person' is ignorant of the value or destiny attached to each head but in any case, whatever the person chooses would be the destiny attached to it. All choose at the same place but each chooses a different destiny. Those who choose well-formed ori would endure the rigor of the journey into the world. Such will succeed in life without much struggle. Those who select the illformed ori would almost have their ori worn out before arriving on earth. As a result, they mostly strive to no avail in life. The person moves on to meet Oníbodè (the Gatekeeper) and comes into the world.

While suggesting a reconstruction of these two accounts Segun Gbadegesin (1991:37) sees the latter account as more plausible. It gives a vivid description of how every individual chooses his ori (personality self) which is ordinarily conceived as the determinant of human personality, whereas; the former account relays the ori itself kneeling to choose the destiny. It is not logically feasible that the personality self can be determined before choosing the destiny. Hence, Gbadegesin asserts that it would be better to replace in the first account, where ori is pictured kneeling to select the destiny to Ara and èmí (body and spirit) in the second account as kneeling down to select the ori. Since ori by interpretation is human destiny, it would then be that the Ara and èmí (body and spirit) kneel down before Olódùmarè (God) to acquire the destiny most conceivable by oral pronouncement. No object is selected by the person whether physical or otherwise (Gbadegesin 37). Hence, there would be no allowance for the selection of any substance representing orí in any form, and the Olódùmarè just sanctions whatever is declared by the 'person'. He further observed that this tentative solution has the tendency of raising some other questions. For instance, it eradicates the place of the Ajàlá Alámò (the potter of human ori, head), negates the Yorùbá understanding of ori as a spiritual component of personality and objects to the Yoruba's reference to ori through offerings and supplications. In responding to these, it might be argued that the Ifá poetry's reference to Àjàlá (the potter of human's head) might be understood metaphorically as what lies ahead of an individual on earth. To handle these two questions an alternative interpretation and reconstruction is hereby suggested.

This alternative may be viewed with the intention of giving a constituent opinion on the process of 
selection of human destiny or Ori by the pre-existent person. In as much as both Idowu (who attributed his source to the oral tradition) and Abimbola (who derived his source from the Ifá poetry) are well acquainted with the Yoruba tradition as insiders and great components of the elements of the oral tradition are as well contained in the Ifá poetry and vice versa, the two accounts can be merged. If this is probable by the frame of our ongoing speculation we will say that Òrìsà-Nlá fashioned the ara (body). The Olódùmarè supplied èmi (life). At this point, the ènìàn, (the person) could then move. He moved to the house of Ajàlá Alámò to select the orí (head) (most possibly by oral pronouncement) and came back to the court of Olódùmarè kneeling to report to him what he has chosen, and receives the blessings of Olódùmarè. The individual now continues on the journey into the world. He encounters the Oníbodè (The Gate Keeper) at the gates linking heaven and earth who also reiterates what Olódùmarè has said. If we see it this way, the view of the place of the Àjàlá Alámò might be preserved and the appreciative status of ori to a level as a spiritual component of human personality will also be affirmed. However, the intended purpose of the myths when considered independently is the subject of another discussion.

In Yoruba cosmology, a human being is thought of as a creature with parts and components. There are diverse opinions among the scholars but in spite of this diversity, there are points of agreement. I will attempt a description of the ènìyàn (human person) via the Yoruba philosophical language for ènìyàn, with the consciousness of a religious worldview, namely; ara (body), èmí, (spirit/life), okàn, (mind/heart) or soul and Orí, (the personality self). Each of these three is uniquely important in its own way. Both Makinde (1984:189-200) and Gbadegesin (1984:173-188) have the same opinion that eniyan (humankind) is a tripartite being. This view shall be presented in a diagram before considering different components. ${ }^{1}$

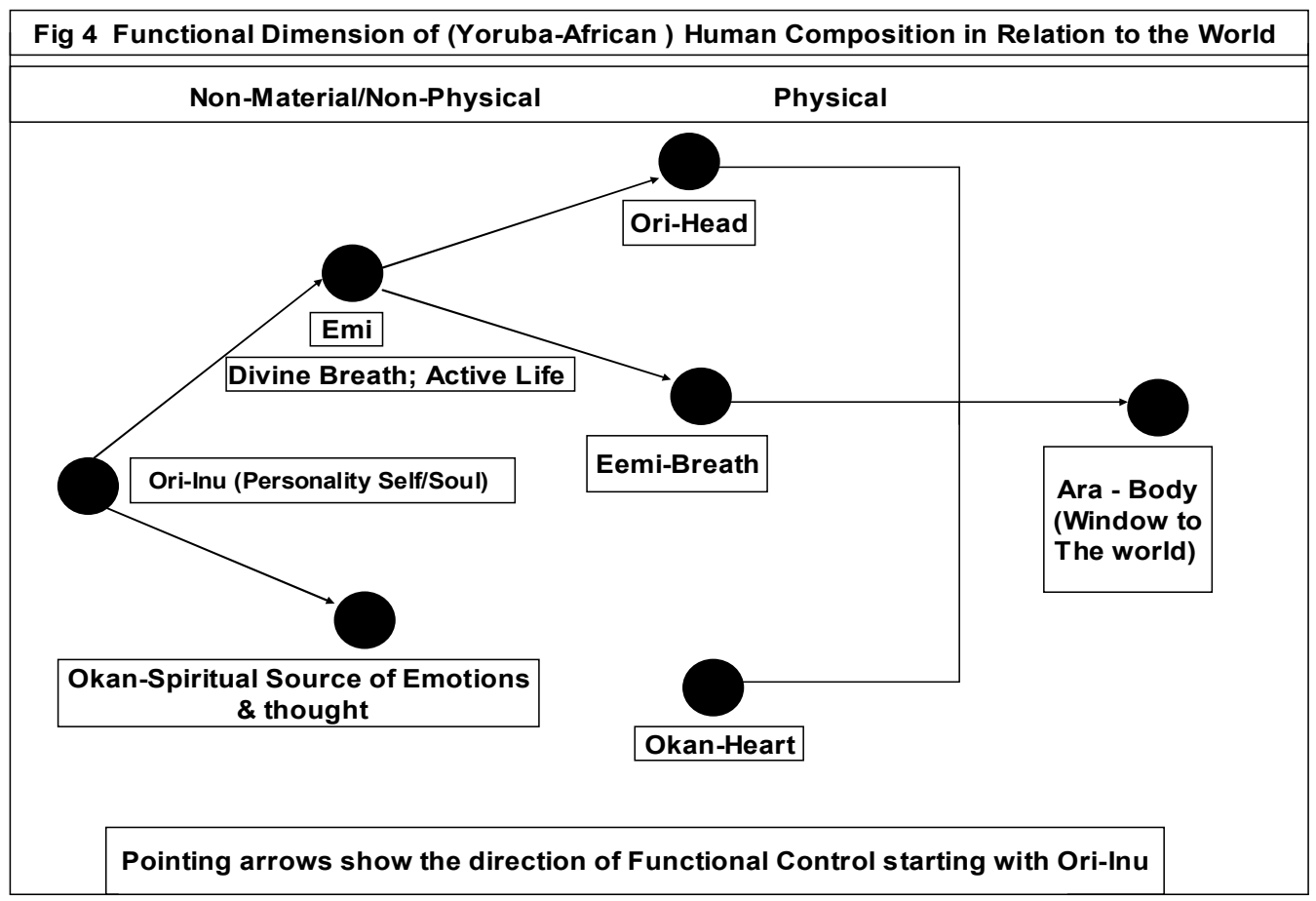

Fig. 4. Functional dimension of (Yoruba-African) human composition in relation to the world (source: Segun Gbadegesin)

\subsection{Ara, The body}

Ara (the body) is the material part of the human. As a physico-material substance, it encapsulates both internal and external constituents; flesh, bone, heart, intestine and so on. It can also be given a physical description, heavy or light, strong or weak, hot or cold (Gbadegesin 1991:28). The body is seen as the window to the entire

\footnotetext{
${ }^{1}$ See Gbadegesin 1991:41. I owe the Figure diagram to Gbadegesin and I have adopted it for two reasons. Firstly, as a Yoruba philosopher, he shares this worldview and tries to represent it by using appropriate Yoruba words with corresponding English vocabulary. Secondly, he brings together the physical and non-physical parts of man to show their functional relationship.
} 
universe, in which the senses are disposed to aid the acquaintances to the rest of the world.

\subsection{Emí, The spirit}

The second part is the èmi (spirit or breath of life) which accounts for the liveliness of the body. This is the nonphysical part of man. It is that which brings breathing (èémi) as the process of continuous livelihood. The nature of èmí (just as it is in the western philosophical tradition) is both spiritual and has an independent existence. In Yoruba view, the èmi can have a temporary separation from the body (for whatever purpose) while the èémi (breathing) continues and later returns into the body. There are objections raised against the nature of the spirit. The èmí cannot remain spiritual when it still occupies the space to be re-embodied, and that it cannot have independent existence since it is rather a force than an entity. However, since Olódùmarè himself is spiritual (non-physical) yet exists as an independent being and that the èmí (spirit) has already been attributed as part of the existence of Olódùmarè, then, the èmí (spirit) can have self-existing tendencies outside the body (Salami 1991:4-15). For them, since the èmí (spirit) is self-existing immortality is a certainty. Furthermore, we may use the term of Socrates to describe the death of the body as the separation of the spirit from the body.

\subsection{Okàn (Heart/Mind)}

It is mostly translated as soul or heart and sometimes as mind. The translation as the soul does not carry the full meaning of the word in the Yoruba language. These translations are suggestive in two ways. That is, we may understand okàn as primarily part of the body, heart which is physical in nature. It can further be understood in terms of what Descartes called "the thinking thing" or what D.M. Armstrong referred to as the "the brain" (Ornstein: 1972:120). According to Yoruba people, okàn is understood as the seat of emotion and psychic energy (Idowu 170; Gbadegesin 1991:29-33). Therefore, okàn is more of a mentalistic function than a physical organ in relation to our discussion here.

5.5 Ori (The Personality Self or Personality Soul)

The Ori is variously translated as personality self, personality soul, the bearer of destiny, and one's guardian spirit. The concept of ori (personality self) can be understood in two ways; literally and symbolically. Literally, it means the physical head as a part of the body. If it is given a symbolic interpretation, it implies 'the inner head' which everyone chooses before this existence and which distinguishes one person from another just as the fingerprints.

However, from the Yoruba cosmological perspective, the human person is not complete without the consideration of the ori. This third component of human personality marked a total departure from the Western dualistic theory of human personality. 'Inu'' (the inner head) as ori as synonymously called, is also associated with and sometimes used interchangeably with èmi (spirit) (just as the mind and soul are sometimes used interchangeably). Hallen and Sodipo (Hallen and Sodipo 1994:3-21) observed that inú as the self 'houses' intellect opolo, wisdom ogbon, character ìwà, and patience sùurù. They further agreed that all the 'occupants' of inú are rather psychological capacities of every individual. Thus:

Emi is usually defined in metaphysical terms, while inu is here defined psychologically or epistemologically. Emi is said to be roughly equivalent to the 'spirit' or 'vital element' of the person that survives death and reincarnated an indefinite number of times. While inu, as we have seen above, is explained in terms which render it much closer to a psychological self that is not directly assigned any obvious, comparatively metaphysical status (Hallen and Sodipo 15).

Both the metaphysical and physical aspects of the person are interrelated through personal observation and analysis. Ori is often described as a person's divinity that is chosen and as such, it should be adorned. However, Idowu is more detailed when he described ori as the personality soul (Idowu 170). For Idowu, if we must understand ori (literally translated head but in this case translated as personality soul), we must trace it to the Orísè, "The Head-Source", from whom we all descended, Olódùmarè himself (Idowu 170).

The relationships between all these components are not far-fetched. Ara (the body) is physical and material, èmi (spirit) is both mental and spiritual while ori and okàn have both physical and mental dimensions (see figure 4). The mental dimension of okàn is responsible for the thoughts, thinking or wishing, etc. If we follow this pattern of thought, okàn might be merged with the personality soul as its component. If this stands, we can then have a distinct Yoruba dualistic concept of a human person. Ori, in addition to being a physical part also has the spiritual component which accounts for human personality and distinctiveness. In this way, the emotional component of the human person, thinking ability and the power of wishful desires are all contained in the chosen ori but finds expression in various forms during one's lifetime. Moreover, the body is of the same substance to all, the spirit as infused by Olódùmarè is common to all but the personality self is uniquely different. Hence, in line with logical reasoning and empirical observation, it is attributable that whatever affects the body is 
potentially dangerous for other components of the body. For instance, heart failure or bodily injury can lead to the death of the body.

\title{
6 Concept of Death
}

Death is a physical separation of a person and his community. It is an event interjecting between two worlds, the world of humans and the world of spirits, between the two natures of humans, visible and the invisible (Mbiti 149). Thus, for Yoruba people, it does not bring the spiritual separation between the living and the departed. Rather it further gives the tendency of the greater support from the departed ones to a clan or community.

6.1 Myths about Death

J.G. Frazer (1913:31-86) in chapter two and three of his book the Belief in Immortality narrated various myths about the origin of death. Another luminous attempt was made by Hans Abrahamsson (1951:1-128; Beier 1966) when he classified the myths about death from different nations and peoples in Africa into about twenty-two major headings. There is, however, one myth that is particular to the Yoruba people, which depicts Ikú (death) as a good person who became notorious for killing other humans when his mother was killed at Ejìgbò-Mekùn market (Idowu 186). This is stated as follow as contained in the Òèkú-méjil of Ifá Corpus as quoted by Idowu:

\author{
Nwon pa ìá ikú \\ S'ojà Ėjìgbò-Mekun: \\ Ikú gbo n'le, \\ Ikú han bi àgon Il'óye \\ Ikú han bi eyin arawo; \\ Of'oká se késé, \\ Of'ere se bàtà, \\ Ikú ta ori ìgba, \\ Igba gbirì'à n'lè; \\ Ikú ta ori ègungun, \\ Translation \\ Ègungun gbirì'à n'lè. \\ Ikú's mother was killed \\ In Ejìgbò-Mekùn market: \\ Ikú heard it in the house, \\ Ikú screeched like the àgon ${ }^{2}$ of Il'óye, \\ Ikú rang out like an arawo 's ${ }^{3}$ egg; \\ He made cobras his spurs, \\ He made boas his shoes, \\ He made scorpions his girdle; \\ Ikú fell upon the Locust Bean Tree, \\ The Locust Bean Tree fell prone to the ground; \\ Ikú fell upon the White Silk Cotton Tree, \\ The White Silk Cotton Tree fell prone to the ground (Idowu 186ff).
}

This account seems to show when Death began to kill as revenge to his mother's slain. A much stronger belief is that Iku (death) is rather a personified power that is carrying out orders from Olódùmarè to remove those who have completed their time on earth, usually the elderly ones. Death in this sense then is a messenger of Olódùmarè. If those who have spent their allotted time on earth are interpreted as the elderly people, how can we account for the infant and youth mortality? The people attempt to differentiate between the death of an elder which is described as 'returning home' and a forceful death through the forces of Ajogun (certain forces that terminate human life like illness, infirmity, or disaster or even an auto crash) which may lead to death before one's time is fulfilled. However, giving certain conditions any of these can be prevented.

\footnotetext{
${ }^{1}$ Òyèku-méjì is one major Odù out of the 16 major Odù in Ifá Corpus.

2 Agon is described as a re-enactment of the origin of a Yoruba secret cult. The 'character' is not to be seen by anyone and screeches its messages unnatural tones thereby conveying the understanding of a non-human agent behind it.

${ }^{3}$ Arawo is known to be a carnivorous bird.
} 


\section{$7 \quad$ What Happens to a Person in Death?}

The Yoruba conception of death is that of transition other than annihilation. After death, an individual is prepared for personal immortality. Those who before passing on have children are said to be replaced by their children. In this respect the children are the image of the parents after their parents. At death, the soul departs from the body leaving the latter empty ready for decomposition. There is a transition into another world. The context of the interpretation of that 'another' world is what I shall be focusing on shortly.

\subsection{What and Where of After-Life}

In the Yoruba cosmology, it is assumed that there is a partial separation between the spiritual and the physical world. The occupants of 'the other world' can visit this world at will, and vice versa (see fig 4). This is not a claim that anyone can embark on such an adventure. One of my informants asserts that with the aid of certain metaphysical power, some are able to make contact with the world of the dead. The Yoruba notion of Ėhin-İwà (a state of after-life) immortality will be considered. Idowu writes concerning Èhin-Ìwà;

After death, therefore, man passes into a "life beyond" which is called Èhin-İwà- "After- Life". This Èhin-İwà is of more vital importance than the present life, however prosperous this may have been. The Yoruba speak thus of Èhin-İwà ti 's' ègbon òní - After- Life which is the superior of Today (the present) (Idowu 189).

Salami writing on immortality in Yoruba cosmology takes a clue from Makinde; "immortality in Yoruba language means 'aiku'(deathlessness) ... While Olódùmarè (God) is known as 'Oba aiku' (i.e. the deathless or immortal king). His breath as breathed into the life-less body of man makes him (man) a living soul" (Salami 1991:13). The implication of the above is that part of the immortality of Olódumarè has been given to every human when he was given the breath of life. Hence, it is only after the bodily death that a human being comes to realise the fullness of immortality. It further affirms the deathless and indestructible nature of the soul of a human person. Salami emphasises further the Yoruba belief in immortality to the concept of the day of reckoning when the Olódùmarè will revisit all human actions. It is also maintained that the judgement is personal in nature. This is against the postulation of some that there is no judgement after death among Africans. Such school of thought possibly influenced by their immediate culture and tradition hold that after death the witch continues to be a witch, the wicked continues to exist and the good person continues to exist as such (Nyirongo 1997:71-78). That is not contained in Yoruba thought.

The notion of immortality is yet found in the practices such as telepathy and spirit communication with the dead. There are certain individuals who possess metaphysical powers to initiate telepathic communication with the dead. There is much difference between the Western and African concepts of telepathy. Those who have such powers never give psychological explanations for it. Instead, they attribute it to some other cosmic powers. It is also good to refer to the phenomena of dreams. A popular Yoruba dirge contains these words;

Ó di gbéré!

O d'à-rin-nà kò!

Ipade di oju ala firi,

O d'òrun alákeji!

Translation

It is a long farewell!

It is now a matter of meeting along the road,

(It is also translated as never we meet again on the road, emphasis is mine),

It is now in dreams (that we shall meet) faintly.

We shall meet in alákeji ${ }^{1}$ heaven (Idowu 191).

The belief in the deceased appearances in the dreams to the family and friends are held firmly. It is believed that the departed ones can send messages and give instructions in dreams. In the above dirge, the post-mortem state is briefly described as a dream-world where imagery gives no full comprehension of the state of affairs but still engages in a sort of communication. It is said that the deceased and their relatives never meet again along the road, although may meet in dreams. If the notion of after-life is then conceivable among the Yoruba people, where, hypothetically, is its location? Some of the Yoruba speculations on this shall follow in this discussion.

7.2 The Abode of the Deity

A vast majority of people envisage that the place of after-life (where the dead reside) is the abode of Olódùmarè.

${ }^{1}$ The Alákeji has the notion that seven heavens exist. 
Firstly, the Yoruba word for heaven is Orun; the sky is called ojú òrun (heaven's face to render it literal or heaven's veil). Orun heaven then is a place beyond the sky. So, a deceased is said to have gone to heaven. Secondly, this assumption is more specifically related to the view of post-mortem judgement. The final judgement resides with Olódùmarè in Orun who 'separates the wheat from the chaffs' by visiting individual's character in material existence. He alone finally decides the good and evil. The good are relocated to Orun -rere (good heaven) which is also referred to as 'òrun- baba eni' (the heaven of one's father); while the evil doers will be relocated to 'òrun buburu' (bad heaven) or òrun àpádi (the potsherds heaven). Those who are described to be in the first category of heaven have been discharged and certified worthy on the basis of their character by the Olódùmarè. Those are said to be in the second category of heaven are found wanton and would remain there eternally.

\title{
7.3 'Ajiran Theory' (The City of the Dead)
}

Three sources account for this presupposition, oral tradition, NDEs and dreams experiences. These three dimensions have some things to say about life in post-mortem world. The impression one gets from such narratives (of the above phenomena) is the description of a city with numerous inhabitants situated shortly after the crossing of a river. It is described as a walled city with a wide gate that is only accessible to those who have finished their course on earth - to join the inhabitants therein (Wiredu 1992:137-152). Traditionally the transition into another world has been interpreted as a journey. It is described in some ways as if the location is not totally separated from this world but that could be 'accessible by walking' as people often say something like, 'then I was going... I crossed a river...' Another assumption is that the experient gets to the gate, knocks and one of the deceased relatives comes out to drive the person back.

The legendary Ajiran city is described as a 'gate city' between heaven and earth (Idowu 181-182). The head of that community is referred to as Ayórunbò (the one who goes to heaven and returns). The life there is often conceived as normal life on earth like eating, doing all sort of transactions, etc. A Yoruba dirge to a departing soul supports this:

$$
\begin{aligned}
& \text { Má jò̀ùn, } \\
& \text { Má je'kòló; } \\
& \text { Ohun tí wón bá nje lájùlé òrun, } \\
& \text { Ni kó ma- bá won je. }
\end{aligned}
$$

Translation

\author{
Don't eat millipedes, \\ Don't eat earthworms; \\ But whatever good things they eat in heaven, \\ Eat with them.
}

This gives the notion that those in that city or that world also feed and exist, may be to say 'as it is on earth so it is in the heaven'. It is not so clear whether these persons inhabit Ajiran temporarily or remain there permanently. All we can say for now is that such an idea as this is known among the Yoruba people.

\subsection{Earthly Relocation Theory}

The old age is viewed as a gift to all human beings. When an elderly person dies he is believed to join the ancestors shortly and such death is interpreted as a godly-ripe death. Those who die mysteriously or prematurely through sickness, accident or human forces or generally before their allotted time have to complete their remaining life cycle. The latter category of people normally is not allowed into heaven. They are said to relocate to the desired place to continue the normal life again. Such individuals are called Àkúdà-áyà (a dead person who reappears at another location to live a normal life). ${ }^{l}$ Such persons retain every form of identity including the facial appearance as before the untimely death. The mysterious side of this idea is that the day that one of the acquaintances this reappearing person hears that he/she has died would be the last day he will see him again. In essence, since the identity has been revealed as an Ákúdà-áyà, he relocates again to another location until his allotted time is completed. One of my informants claimed to have encountered a situation like this.

If the above narrative is conceivable, that through the report of the eyewitnesses we accept this possibility, can this be regarded as an after-life? The response can hardly be in affirmative since the individual continues and possibly dies eventually. It must be admitted that there are limitations as mortals, at least, within

\footnotetext{
${ }^{1}$ The notion of Àkúdà-áyà a relocation of some deceased individuals to another location for the completion of the allotted earthly life was developed among Yoruba-Africans to accommodate some strange but true occurrences of life experiences about people who have died in some places and are said to reappear in other places.
} 
the present speculative orientation and there are mysteries which are yet to be unraveled.

\subsection{Partial Reincarnation}

The aim of this part is to present a notion of reincarnation that is held among the Yoruba people. First, we shall deviate totally from the popular concept of karmanic reincarnation that is fondly held in Indian Samsara - series of rebirths. It is held in the Yoruba idea that the individual person is a unique entity. The deceased ancestor still remains in the abode of the spirit but the soul takes characteristic features of the life of the deceased person in the family and usually coming in grandchildren and great-grandchildren. (Idowu 194-195). That is the reason it is called a partial reincarnation. Bolaji Idowu comments:

In African belief, there is no reincarnation in the classical sense. One can only speak of partial or, more precisely, apparent reincarnation, if the word must be used, at all. There is a belief in certain areas that ancestors return in one or several children in the family (Idowu 1973:187).

Idowu sounds a caution in using the term reincarnation with the nature of this present inquiry. The purpose of this is to show differences between the Yoruba concept and metempsychosis or transmigration of the soul. The reincarnated persons are known through a traditional rite called 'mimo ori omo' (knowing the child's head). The parents contact the oracle in traditional society to know the ancestor that has returned.

A.O. Echeknube (1987:10-25) has followed Mbiti (164) as well as Awolalu (1979:59-60) in suggesting reasons for the possibility of reincarnation. It is traceable to the consciousness of the closeness of the ancestors to the family all the time, and the other is, a possible influence of hereditary traits and genetic interference. That is, to say, since the parents themselves resemble their parents, one of their own children has a tendency of taking after them and even the ones they also take after.

There is another form of reincarnation that is seen in cases of àbik $\dot{u}$ 'born to die' children. "The disguised soul of àbikú is only like a tourist; for it will soon desert the 'borrowed' in order to return to its unborn companions" (Lawal 1977:55). The àbikú are born but live and die shortly and come back again. Children in this category usually exhibit strange behaviors. Those who give birth to such children identify them through certain marks on the body having experienced such infant death for a while. They later find out during subsequent birth that a mark appears in the place the child has been cut.

\subsection{Summary}

An exploration of the Yoruba concept of death and immortality in this section has been based primarily on the three major aspects of this inquiry. It has been shown that Yoruba people have exclusive worldviews which inform their beliefs and philosophy. A human person is seen as both spiritual and physical. In the human composition, there is ara (body), èmí (spirit), and orí (Soul) that is often translated differently as personality self or the personality soul. It is conceived as the object of worship and the bearer of destiny. There are, however, some difficulties here including the proper interpretation of the Yoruba concept of the soul Ori as a personality self in a Western view. Also, it seems that little or no explanation is given to the mind/brain relationship with which the Western philosophers are preoccupied. Nevertheless, the Yoruba identified the mind/heart (okàn) in two forms, one is the physical organ in the body and the other is the unseen substance that correlates with the brain in thinking as it is in the western tradition.

It has also been shown that at death the èmí plus Orí (spirit +Soul) depart (with the soul embodying the spirit) from the ara (body) into the spirit world. The person lives on peacefully on the basis of his character here on earth. The Ori (soul) of an ancestor can reincarnate in his grandchildren or great-grandchildren. This might not be limited to an individual but the similitude can be in many children as a result of which no one can claim the monopoly of the reincarnation of an ancestor's ori. Despite this, the ancestor is said to be in his/her restful state in the spirit world.

Yoruba people have various places for the afterlife that are variously backed up by different sources. Some might relocate earthly to continue their life cycle in cases of those who die prematurely. The court of Olódùmarè is mostly supported in other cases. The dead are said to appear to their loved ones when necessary to give instructions or to support them. Another place that has been suggested is the Ajiran (the city of the dead) the location of which has been suggested to be in various places. Those who have the knowledge of certain metaphysical assistance could get there. Needless to say, is the fact that the location of the after-life is somewhere yet to be revealed. In which case, the Yoruba do not take all these information hook lines and sinker some are skeptical on them as well. For instance, one of my informants, a ninety-five-year-old that after forty years of serving as a night guard at a cemetery he has never seen a dead person.

In all speculations and analysis on the Yoruba idea of death, I have attempted to show that Yoruba people have a conception of immortality through their constant reference to the Yoruba philosophical sources and with inference or reference to the basic assumptions at the beginning of this section. 


\section{Comparison of John Hick and Yoruba Philosophies}

8.1 Human Nature in Relation to Death

Both Hick and the Yoruba people accommodate a tripartite nature of the human person comprising the body, soul and spirit or atman. Hick's discussion on the mind/brain in relation to the survival of bodily death holds that mind, though an independent entity from the brain is capable of having an influence on the brain and vice versa. It is disproved of a unilateral approach. Rather, it gives allowance for a mutually interdependent relationship. This is possibly the reason for some who have narrated NDEs. Most of his emphasis centres on mind/brain relationship. There is an undeniable interaction between the body and the soul.

The Yoruba holds a unique tripartite view of the human person with the elements ara (body), èmi (spirit) and ori (soul/personality self). The mind in Yoruba thought is both mentalistic and physical in nature (see fig. 5). The mental nature is non-physical and with it, an individual thinks and takes a decision. The body is equivalent to ara (in Yoruba thought) the spirit is also related to èmi. The third part, soul, though with the same spelling when given an English equivalence but has different conceptual interpretations. To this end, it is the determinant of individual personality. For Yoruba people, the person himself is this ori, the personality self. Hick and the Yoruba people believe that the body is the only component that dies while the soul survives the bodily death into another level of existence but are different in their understanding of the next level of existence after death.

8.2 What Happens in Death and possible place of afterlife

As a proponent of religious plurality, Hick draws ample inspiration from the Eastern alternative thoughts as found in reincarnation. The main notion of reincarnation is to offer understandable explanations for all the disproportionate events in life. The concept of reincarnation as seen among the Yoruba people is an apparent reincarnation. Here, the personality constituent, that is the Ori, is the only element that reincarnates always in a family line. The physical or facial appearance, mannerisms and other sorts of the identity of a deceased ancestor can be reproduced in the same family line in several of his/her grandchildren and great-grandchildren while the ancestor is believed to still be in a restful status in the ancestral world. A critical look at the Yoruba and Hick concept of the soul shows that they are homonyms rather than synonyms. The purpose of the presumed reincarnation in Yoruba thought is to retain the presence of certain desirable qualities and to sustain the existence of the family line. The purpose as shown in karma is to correct certain inequalities. The concept of reincarnation of the Eastern religions which Hick affirms involves the total person excluding the physical body while the Yoruba notion is limited to the characteristics described above. The view that an individual can reincarnate into a plant or an animal or even a reptile on the basis of character is not prominent among the Yoruba people. Even in the eastern traditions form of reincarnation, it is questionable whether an individual who reincarnates into a reptile or an animal can still reincarnate back into a human being again. If yes, what will be the basis? If no, then, since reincarnation is said to be an endless cycle of rebirth, karma will be partial to some except such individuals can redeem their behavior to benefit other humans either as a substance or as a human being. These questions can actually go beyond the scope of this section. In this case, the theistic option may serve as a bailout here.

In considering a possible place for after-life, Hick's speculation is that of a successive space. He sees it as a world of its own with distinct adaptability and features. The notion of the place of after-life has been variously suggested among the Yoruba people as the court of the Supreme Being or the city of the dead. If the abode of the Supreme Being is suggested and it is believed that only the faithful would eventually dwell with the Supreme Being, it gives a further possibility of a place the Yoruba call òrun àpádì (pot-sherd-heaven) which is presumably a place for the wicked. The observations made in this section lead to pointing out certain similarities and differences.

\subsection{Religio-philosophical speculation}

The faith traditions within which both Hick and the Yoruba people engage in their speculations are very rich in their different cultural contexts. Hick's use of eastern philosophical and religious systems showed his openness to any available data from diverse religious traditions that could aid his speculation. Both Hick and Yoruba people have their discussion within different religio-cultural spheres. However, the main difference is that Hick fond of advocating the propositions of other faiths and synthesizing them accordingly while the Yoruba understand such views as expressed in other traditions exist but never goes to the extreme of advocating them as Hick. But they accept that they can be a means of understanding other religions and their doctrines.

8.4 Purpose of the present life

Another visible area in which there is a contrast between Hick and Yoruba thoughts relates to the purpose of the present life. The Yoruba people in their thinking believe that the goal of the present life is to benefit one's family and community through compassionate character and to live peaceably with the good-will and pleasure of the Supreme Mind and the ancestors. Hence, it is meant to acquire a good character as the sustaining component for 
after-life. The present life has a limit in its scope, anything that is good or bad with a good or bad intention cannot be redeemed after death. Hick, in his thinking, believes that the essence of the present life is for the purging of human's character and the making of his soul (Hick 1966:355-400). He proposes a series of lives in successive order. This process is highly necessary as it begins at birth with an interlude of death and continues serially at another birth in consecutive order.

8.5 Questions on the Yoruba thought

Many questions can be raised on the Yoruba concept of immortality. It has been noted earlier that ara (body) and èmí (spirit) made a choice of ori (the personality soul or self). The question is, in this prenatal state how possible would it be that ara which is a physical entity would be available in conjunction with èmí (spirit) to make a choice of ori? (Gbadegesin 1991:39). Further, it becomes more problematic at least from a Western perspective when considering the exalted position of the ori to the status of a personal divinity and at the same time as personality soul. For one, it is clear that any scientific examination of the human body cannot detect anything like orí. It is capable of conveying an erroneous conception of orí or its rejection as 'a part' of the human person but as one of the divinities.

Again, individual destiny is another issue of relevant ambiguity. It is explained that the individual has chosen his or her destiny in heaven before coming into the world which later unfolds accordingly in the course of life. Yet it does not leave out the possibility of either changing it by human forces or strengthened it by appeasing the arch-divinity, Orúnmílà with certain prescribed conditions. That it has been chosen by kneeling or received through kneeling or affixed to one and finally sealed by Olódùmarè underscores the fact of its unalterable nature. Additionally, it is more supported by life situations than in theoretical analysis that destiny is sealed ad infinitum. Philosophically, to say that an acquired destiny has been sealed by Olódùmarè is to say that it has been canonized. It cannot be changed. Or to say that it can be changed now is to mean that it is still left open. A pragmatic approach to responding to this critique in Yoruba notion is to say that destiny is canonized and closed as well as open in some respect. It is often reasoned that some events in life can be changed if one is aware early enough. At the other extreme, some happenings are said to be irremediable.

The last aspect of our critique here relates to the notion of reincarnation, the true identity of the reincarnated ancestor. It is claimed that a deceased ancestor reincarnates in the same family in grandchildren and great-grandchildren. Could a reincarnated ancestor take the same body or spirit or personality soul (as before death) while reincarnating? What conditions would help in identifying the reincarnation of a deceased ancestor?

It is necessary to seek redress again to the Yoruba understanding of the conceivable reincarnation. To understand it properly as one which is partial would help to explain that it is not the spirit and the personality soul that reincarnates rather it is the personality soul constituent. To say that it is the spirit and personality soul that reincarnate would connect to transmigration. In another way, the ancestor remains in the world beyond while some features traceable to him or her are identifiable in his grandchildren. These are often detected through a traditional rite that is specifically designed for that purpose after necessary consultation. Another way through which a reincarnated ancestor may be known is the memory of previous life. The responses given above raise another question of how one personality soul is possibly distributed among many in a family.

It is evident from the foregoing that the distinct nature of Yoruba formulations on the notion of immortality prompts many questions to which we have attempted to react. It is against this background that Oladipo (1992:36-49) raises a view of determinism in matters of Yoruba thoughts. In a reassessment of the above one may possibly say that this determinism is partly cultural and theological. Besides, one thing is fundamental in all these questions raised on Yoruba view that cannot be undermined. The interpretative analysis of the Yoruba is philosophically and religiously conditioned to the primary worldview within which all the above interpretations are given. The context of the formulations influences their interpretations and analyses.

8.6 Questions on Hick's thoughts

There are various questions that could be raised on Hick's thought. One of the main critiques here is the consideration of the identity of the 'replica'. This question can come in different forms. "Is the 'replica' and the original person before death one and the same person."? (Cheetham 2003:78) Or could one be convinced enough that the 'replica' has his identity preserved in death that he can still be recognized as the same person? Hick on his part made provision for these questions.

Despite Hick's insistence and confidence, there are reactions from other scholars. Anthony Flew, for example, in his 'Replica Objection' thesis contends that in reconstitutionist perspective, that a deceased is brought back in the same body before death cannot be accounted for as the same person but a mere replica of the deceased (Flew 1976:107). So, as Flew postulates, to reward or punish the replica cannot be justified since their identity is not matching.

Another objection may be considered relating to the above but with specific relevance on time. Time and space are considered as having a contingent relationship with each other. If then the plural spaces as 
proposed exist and the resurrection is conceived as a psycho-physical recreation in another space subsequent to death, how can the time relationship between the two spaces be understood, especially with reference to the events in the pre-mortem and post-mortem world? (Hick 1976:289).

As interesting as these arguments may sound we must, however, sound some cautions. Firstly, it is not all that clear if Hick would be willing to synthesize all these together ('replica' theory and reincarnation) to form a chain of events. This is not most likely going to be in harmony with his main goals in Death and Eternal Life. Secondly, Hick's formulation does not exclude other traditions except we again attempt to locate 'replica' theory within the context of an alternative to the Christian interpretation of the resurrection as an eschatological event and its nature. However, it is not sure the extent to which we can relate 'replica' thesis to reincarnation in principle but in practice, the relatedness of the two cannot be excluded all the same.

\section{Conclusion}

This article constitutes an examination of the visible comparison between the Western and Eastern pareschatologies as seen in Hick and African eschatology as demonstrated in the Yoruba thought. Our postulation till now has really shown that there are possible areas of similarities and that other divergent views also exist. There is an aspect of our reasoning on both sides that we must briefly consider. Hick in his resurrection theory proposes a replication of a deceased in another space. The Yoruba also affirms that subsequent to a person's death there is an appearance in another world of post-mortem existence. It gives the impression of the likelihood of a merger of ideas. It then follows that if this space and the next space are both parallel and public as Hick suggests, and the inhabitants enter it immediately after death, would it not be possible to assume that both Yoruba and Hick are saying the same thing but with different cultural interpretations?

Hick vision of a global theology of death is commendable. It is clear from this article that a global theology or philosophy of death is possible but it requires a collection and analyses of data from different disciplines, religious traditions, and philosophies. It not so sure whether Hick succeeded in his vision of a global theology of death in spite of a wide range of discipline consulted since available data from the largest continent of the world was excluded. However, requires further elaborations and warrants such a comparative analysis that has been done here.

\section{References}

Aquinas, T. (1259-65). 1956. Summa Contra Gentiles II, trans. J.F. Anderson, On the Truth of the Catholic Faith. Garden City, NY: Doubleday.

Abrahamsson, H. (1951). The Origin of Death: Studies in African Mythology. Uppsala: Almqvist \& Wiksells Boktryckeri AB.

Awolalu, J. O. (1979). Yoruba Belief s and Sacrificial Rites. London: Longman Group Limited.

Beier, U. (1966). ed. The Origin of Life and Death: An African Creation Myths. Ibadan:Heinemann educational Books.

Cheetham, D. (2003). John Hick: A Critical Introduction and Reflection. England:Ashgate Publishing Ltd.

Cherry, C. (1995). “Are Near-Death Experiences Really Suggestive of Life after Death?"in Beyond Death: Theological and Philosophical Reflections on Life afterDeath, eds. Dan Cohn-Sherbok and Christopher Lewis. London: Macmillan Press Ltd. 145-163.

Ekanola, A. B. (2006). "A Naturalistic Interpretation of the Yoruba Concept of Ori” Philosophia Africana 9, no. 1, (March): 41- 51.

Echeknube, A.O. (1987). "The Question of Reincarnation in African Religion: A Re-Appraisal" Orita 14, no.1, (June): 10-25.

Frazer, J. G. (1913). The Belief in Immortality and the Worship of the Dead, vol. 1,London: Macmillan \& Co.

Gbadegesin, E. O. (1984). "Destiny, Personality and the Ultimate Reality of Human Existence: A Yoruba Perspective" Ultimate Reality and Meaning 7,no.3:173-188.

Geach, P. (1973). "Immortality" in Immortality, ed. Terence Penelhum. Belmont: Wadsworth Publishing Company. 11-21.

Haldane, E. S. and Ross, G.R.T. eds. (1976). The Philosophical Works of Descartes. LondonNew York: Cambridge University Press.

Hallen, J. B. and Sodipo, J. O. (1994). "The House of the "Inu": Keys to the Structure of a Yoruba Theory of the Self” Quest: Philosophical Discussions 8, no.1 (June):3-21.

Hick, J. Disputed Questions in Theology and the Philosophy of Religion. London:Macmillan Press Ltd, 1993.

Hick, J. (1968). Evil and God of Love. London: Macmillan and Co.

Hick, J. (1976). Death and Eternal Life. London: William Collins Sons and Co.

Hick, J. (1973). "From 'Theology and Verification'" in Immortality, ed. Terence Penelhum. Belmont: Wadsworth publishing Company.

Hergovich, A. et al. (2005). "Paranormal Belief and Religiosity", Journal of Parapsychology 69, no.2 (Fall): 


\section{3-303.}

Idowu, E. B. (1973). African Traditional Religion: A Definition. London: S.M.C. Press Ltd.

Idowu, E. B. (1962). Olodumare: God in Yoruba Belief. London: Longmans, Green and Sons.

Kennedy J. E. (2005). "Personality, Motivations, Believe, Misbelieve and Disbelieve in the Paranormal Phenomena", Journal of Parapsychology 69, no.2 (Fall):263-292.

Lewis, H. D. (1973). The Self and Immortality. London and Basingstoke, 1973.

Makinde, M. A. (1984) “An African Concept of Human Personality: The Yoruba Example.”Ultimate Reality and Meaning 7, no.3:189-200.

Mbiti, J. S. (1969). African Religions and Philosophy. London and Edinburgh: Morrison \& Gibb Ltd.

Nyirongo, L. (1997). The Gods of Africa or God of the Bible the Snare of African Traditional Religion in Biblical Perspective. Potchefstroom Universiteit.

Ornstein, J. H. (1972). The Mind and the Brain: a multi-aspect Interpretation. The Hague:Nijhoff.

Price, H.H. (1973). "Survival and the Idea of "Another World" in Immortality, ed.Terence Penelhum. Belmont: Wadsworth Publishing Company. 21- 47.

Price, H.H. (1995). "What Kind of a 'Next World'?" in Philosophical Interactions with Parapsychology: The Major Writings of H.H. Price on Parapsychology and Survival, ed. Frank B. Dilley. London: Macmillan Press Ltd.

Price, H.H. (1995). “Telepathy and Clairvoyance: Some Philosophical Questions" in Philosophical Interactions with Parapsychology: The Major Writings of H.H. Price on Parapsychology and Survival ed. Frank B. Dilley. London: Macmillan Press Ltd, 1995. 35-59.

Lorimer, D. (1995). “The Near-Death Experiences: A Glimpse of Heaven and Hell?" in Beyond Death: Theological and Philosophical Reflection on Life after Death. 164-172.

Salami, Y. K. (1991). "Human Personality and Immortality in Traditional Yoruba Cosmology" African Marburgensia 24, no.1:4-15.

Vassy, Z. (2004). "A Study of Telepathy by Classical Conditioning” Journal of Parapsychology 68, no.2 (Fall): 323- 350 .

Wiredu, K. (1992). "Death and Afterlife in African Culture" in Person and Community: Ghanaians Philosophical Studies I ed. Kwasi Wiredu and Kwame Gyekye. Washington D.C.: The Council for Research in Values and Philosophy. 137-152.

Encyclopedia of Occultism and Parapsychology, $3^{\text {rd }}$ ed., s.v. "Parapsychology." 